\title{
原著論文
}

\section{体内伝導音のサブワード単位線形予測による音質明瞭化と 調音素性分析を用いた評価}

\author{
福井 和敏, 石光 俊介, 名越 隼人, 山中 貴弘 \\ 広島市立大学大学院
}

\author{
Study of Sound Clarity Method for Body Conducted Speech \\ using Linear Predictive in Sub-word, and \\ Sound Quality Evaluation by means of Articulatory Feature Analysis
}

Kazutoshi FUKUI, Shunsuke ISHIMITSU, Hayato NAGOSHI and Takahiro YAMANAKA

Graduate School of Information Sciences, Hiroshima City University,

3-4-1 Ozuka-higashi, Asa-Minami-ku, Hiroshima-shi, Hiroshima 731-3194, Japan

\begin{abstract}
Japan is presently aging more rapidly than anywhere else in the world. Concurrently, the number of patients suffering speech disorders is increasing every year, and the incidence is higher as age increases. Those suffering from speech disordered face problems with communicating in daily conversation. They are often able to communicate with speech substitutes, but these typically do not provide a sufficient sound frequency range to be understood in conversation. Therefore, we proposed a speech support system using body-conducted speech recognition. This system retrieves speech from body-conducted sound via a transfer function, using recognition to select a sub-word sequence and its duration. In this study, we demonstrate the effectiveness of producing clear bodyconducted speech using a linear predictive coefficient instead of a transfer function. We estimated interval information by heuristic method to divide body-conducted speech into syllables as in past study. In this study, we used continuous sub-word recognition automatically. To confirm the improvement in synthesized speech, a jury test and articulatory feature analysis were employed.
\end{abstract}

Keywords : Body-Conducted Speech, Continuous Sub-word Recognition, Linear Predictive Coefficient

\section{1. は じめに}

世界的に少子高齢化が進む中で，特に高齢者において口腔 および咽頭癌に罹患する人が増加している 11$]$ ，これらの 病気により発声機能を失った場合は代用発声法を習得する ことで機能を補うことができる。しかし, 例えば食道発声法 の場合, 発声音の音量不足, 雑音混入, 習得が難しい等の 欠点がある [2]，その他，音声障害者向けの支援ツールと して音声出力型コミュニケーションエイド（Voice Output Communication Aid, VOCA）があり, 多くの製品が実用化 されている. VOCAでは言語情報は正確に伝達されるが, 利用者の年齢やなまり，発話の癖などの非言語情報を表す ことができない，また，障害者が発声機能を失う前の声を 再現する先行研究 [3,4]では, 障害者の健常な音声を元に モデルを作成するため, 事前に大量学習しなければならな いという課題がある。以上より, 事前学習を必要とせず, 障害者の障害以前の肉声を再現できる発声機能障害者支援 システムが最も有効な支援システムであると考える.

現在，我々は発声時に体の中を伝達するため外乱の影響を 受けにくい体内伝導音 (Body Conducted Sound, BCS)を利 用した発声機能障害者支援システムを開発している [5-7]. 本研究では, 体内伝導音声の明瞭化手法を提案し, さらに その評価法を確立することを目的とする. 先行研究 $[8,9]$
では声帯から口唇までの伝達関数をクロススペクトル法に よって推定していたが，その有効性を確認することができな かった。そこで本研究では新たに音声生成の仕組みに注目 し, 線形予測係数 (Linear Predictive Coefficient, LPC) を 用いて推定した伝達関数による音声合成手法 $[10,11]$ を検 討し，体内伝導音明瞭化の可能性を示唆した。また，LPC を用いて作成した合成音声がどの程度言語情報を再現できて いるかを確認するために聴取実験と調音素性分析を行った。 これにより，障害者音声と比較して，本システムが具体的に 音声のどの部分を再現できるかを特定することができ，また 本システムの課題も明確にすることが期待できる.

\section{2. 発声機能障害者支援システム}

\section{1 システムの目的}

提案システムは, 発声時に生じる体内伝導音声の明暸化 を目的としている。先行研究 $[8,9]$ では, 代用発声時の気 道音声と体内伝導音からクロススペクトル法を用いて声道 の伝達関数を推定し, 駆動音源に伝達関数をフイルタリング することによる音質変換では音質の向上が困難であること を確認した。 そこで，本研究では新たに線形予測係数を用 いて推定した伝達関数によって駆動音源を抽出し, 明瞭化 を行う手法 [12] を提案する.

また, これまで体内伝導音の明瞭化は単語単位で行ってき 
た。しかし，人間の発話内容は多様で不明瞭な発話も多く， 単語単位での音質変換ではこれら多様な単語に対応できな い. そのため, 本研究では単語よりも短いサブワード単位で の音質変換システムも提案する.

さらに，本システムで生成した合成音声の明瞭度を評価す るために聴取実験および調音素性分析を行い，音声障害者の 原音声と比較してどの程度明瞭化されたか確認した。

\section{2 システムの構成}

発声機能障害者支援システムの構成を図 1 に示す。

音源フィル夕理論より, 音声は声帯の振動などの入力信号 を口腔や鼻腔などの声道フィルタに入力した際の出力信号と 考えることができる．本システムでは音声が式 (1) のよう な全極型の伝達関数を持つ声道フィル夕の出力であることを 前提として線形予測分析を用いる

$$
H(z)=\frac{1}{1-a_{1} z^{-1}-a_{2} z^{-2}-\ldots a_{p} z^{-p}}
$$

つまり，伝達関数を規定するパラメータである線形予測係 数 $a_{i}$ を決定することで, 声道フィル夕の共振特性（スペクト ル包絡）と音源振動の振幅スペクトル（駆動音源）を推定す ることができる。このことを利用し，体内伝導音から抽出し た駆動音源を，健常な音声から推定した線形予測係数を用い て導いた声道フィルタを通過させることにより音質の明暸化 を検討した。また，線形予測係数は 20 次とした。

本手法を用いた音声明瞭化の流れを以下に説明する。なお 事前準備として, 健常者音声の音節単位の線形予測係数を推 定し, それらに対応する合成フィルタをあらかじめ作成し, データベース化しておく.

1. 代用音声発声時の体内伝導音を収録し, 体内伝導音認 識を行い音節の区間情報を推定

2. 推定した区間情報をもとに収録した体内伝導音から単 音節を切り出す

3. 切り出した単音節にLPC 分析フィルタを施し, 駆動音 源を抽出

4. 体内伝導音認識結果から音節に対応する合成フィル夕 (線形予測係数) をデータベースより呼び出し, 駆動音源 をフィルタリング

5. 各単音節を結合し，結果を出力

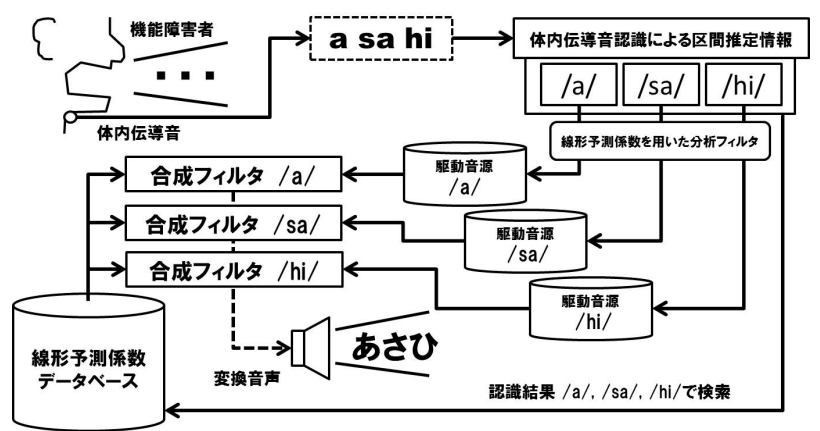

図1 システムの構成

\section{3 システムの特徵}

提案システムの特徴を下記に示す.

\section{・発声時の体内伝導音を使用}

体内伝導音は騒音の影響が少ないため, 騷音に頑強な信号 抽出が可能

・線形子測係数をデータベース化

対応する線形予測係数を呼び出すだけで変換音声を作成

- 音節単位での音質変換

音節の組み合わせで任意の発声に対応可能

\section{・障害者音声の大量学習が不要}

障害前の音声をシステムに大量学習させる必要がないの で，多くの障害者が簡単に利用可能

\section{4 システム評価用音声データベース}

発声機能障害者支援システムの評価のため, 音声デー夕 ベースを作成した [13]．音声は口元から $30 \mathrm{~cm}$ の位置で計測 用マイクロフォンを用いて採取し, 体内伝導音は加速度検出器 を用いて上唇, 声帯, 乳様突起の三か所から抽出した. 音声, 体内伝導音ともにサンプリング周波数 $16 \mathrm{KHz}$ で収録した。

作成した音声と体内伝導音データベースを表 1 に示す. なお，システムによる音声合成に用いるため，健常者の音声 も収録している。

機能障害者1から4は声带に障害のある発声障害であり, 機能障害者 5 のみ構音障害者である。機能障害者 1 は声帯ポ リープ患者, 機能障害者 2 は声帯結節患者, 機能障害者 3 は 片側声帯麻痺患者, 機能障害者 4 は声帯摘出者, 機能障害者 5 は構音障害者として対応付ける。

発話リストを下記に示す。収録時には各リストを 3 回繰り 返して発声してもらった。なお，障害の重度により長時間発 声することが困難な被験者には，読み上げる単語および文章 のリストの数を減らしている.

$$
\begin{aligned}
& \text { 母音：（あ，い，う，え，お］ } \\
& \text { 撥音：［ん］ } \\
& \text { 単語：地名 } 100 \text { 単語 }[14] \\
& \text { 文章： } 50 \text { 文 }[15]
\end{aligned}
$$

また，構音障害者へ対する本システムの有効性を検討する

\begin{tabular}{|c|c|c|c|}
\hline 被験者 & 年齢 & 性別 & 症状 \\
\hline 健常者1 & 22 & 男 & 異常無L \\
\hline 健常者2 & 21 & 男 & 異常無し \\
\hline 健常者3 & 21 & 女 & 異常無し \\
\hline 健常者4 & 21 & 女 & 異常無し \\
\hline 機能障害者1 & 28 & 男 & 声帯ポリープ \\
\hline 機能障害者2 & 30 & 女 & 声帯結束 \\
\hline 機能障害者3 & 80 & 男 & 片側声帯麻痷 \\
\hline 機能障害者4 & 61 & 男 & 声帯全摘出, 音声再建法 \\
\hline 機能障害者5 & 50 & 男 & 舌および顎の一部欠損 \\
\hline
\end{tabular}
ために機能障害者 5 のみ拡大五十音図の発話デー夕も収録し た。実験に使用する音声デー夕は，電子協・地名百選から 抜粋した地名 10 単語を被験者が静寂下において 3 回繰り

表1 体内伝導音データベース 
返し発話した計 30 語を用いた。発話地名は, “旭”, “恵庭”, “八戸”, “気仙沼”, “北見”, “札幌”, “取手”, “萍”, “横手”, “行橋”である。

なお，機能障害者 1 および機能障害者 2 は声帯ポリープ, 声带結束と病名こそ違うが, 症状が酷似しており実験結果も ほぼ同じになったため, 以下の実験考察では機能障害者2を 対象から除いている.

\section{3. システムを用いた合成音声の作成}

\section{1 体内伝導音を用いた認識実験}

予備実験として音声データベース中の障害の程度が異な る男性 5 名 (健常者 1 , 機能障害者 1 , 機能障害者 3 , 機能障 害者 4 , 機能障害者 5）の音声および体内伝導音の離散単語 認識実験を行った。各被験者で障害の程度が異なるため, 本システムがどの程度の障害にまで適用できるか検討する ことができる。認識デコーダにはjulian-v3.1［16］を用い, 音響モデルは性別非依存型の tri-phone モデル, 言語モデルは webテキストから学習した6万単語のbi-gramである [17].

離散単語認識は発声単語数に対する認識率の割合である単 語認識率で評価する。つまり前述の地名 10 単語 $\times 3 セ ッ ト=$ 計 30 語に対してどれだけ認識できたかが単語認識率である。

\section{2 体内伝導音認識実験の結果}

各被験者における全信号収録部位の離散単語認識率を図 2 に示す.

図2より，健常者においても体内伝導音では認識率が低下 していることが分かる. 最も音声に音響的特徵が近い上唇 BCS [18] では83.3\%だが, 声帯BCS および乳様突起BCS ではそれぞれ $50 \%, 30 \%$ と半分程度の認識しかされていな い.これは気道音声と体内伝導音では音響的特徵が異なるう え，本実験で使用している音響モデルが気道音声に基づいて 作られていることが認識率低下の原因になっている.

また障害者において, 音声障害者である声帯ポリープ患者 (機能障害者1), 片側声帯麻痺患者 (機能障害者 3 ), 声帯摘 出者（機能障害者4）は気道音声の認識率は $50 \%$ を超えてい るが，体内伝導音の認識率が非常に悪いことが確認できる。 これは健常者と比較して音声が不明瞭なため体内伝導音 も同様に不明瞭になり，認識率を更に低下させているためだ と思われる。構音障害者（機能障害者5）の認識率は音声で $10 \%$ 程度であり, 他の部位では全く認識できていない.これは

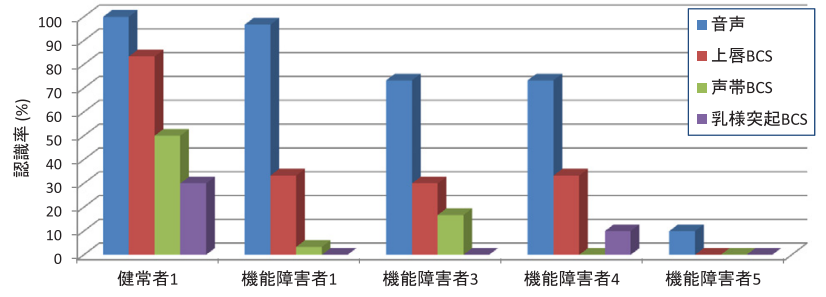

図2 音声, 体内伝導音の音声認識結果
構音が音声に意味付けを行う器官であり，障害になることで 子音等の情報が正確に生成できないためであると考えられる.

本研究では, これらの結果を踏まえ, 明瞭化の対象を上唇 で抽出した体内伝導音のみとした。

図3 から図7に各被験者が地名“旭”を発話したときの音声 および体内伝導音を示す。四の左側が音声，右側が体内伝導 音で，体内伝導音は上唇で収録したデー夕を表示している。 上はスペクトログラム，下は音声波形である。
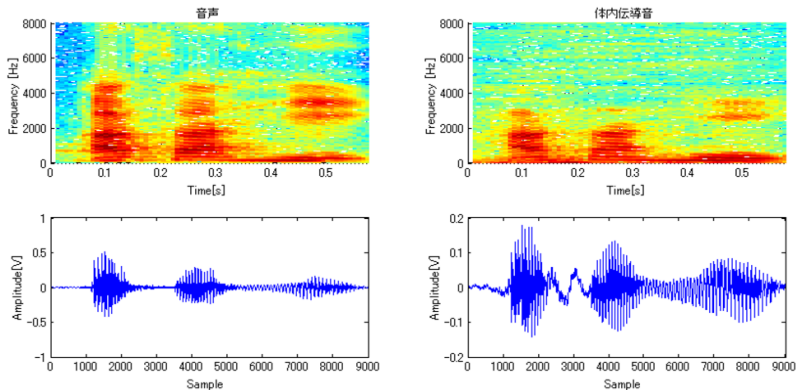

図3 健常者
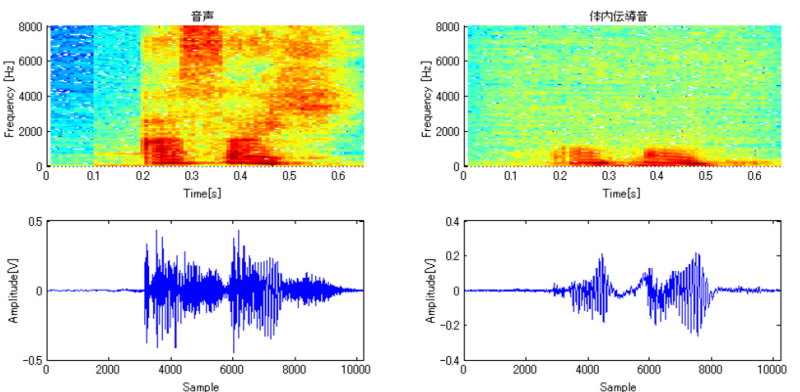

図4 機能障害者1: 声帯ポリープ
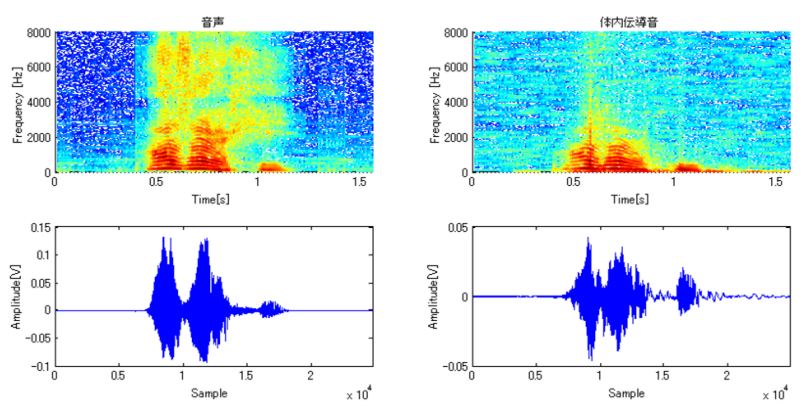

図 5 機能障害者 $3:$ 片側声帯麻痺
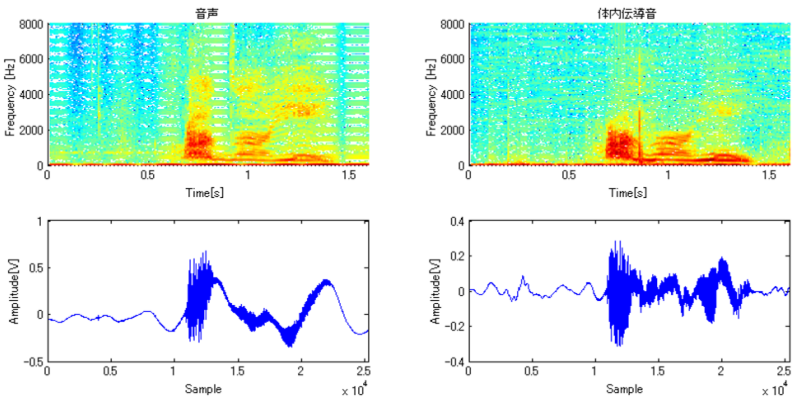

図6 機能障害者 4 : 声帯摘出 

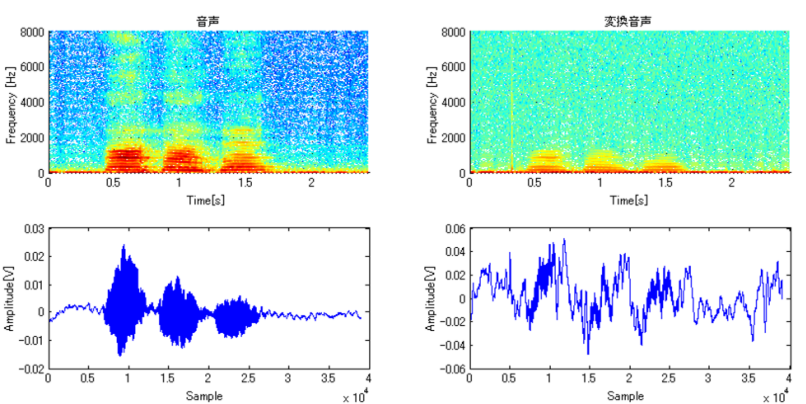

図 7 機能障害者 5 : 構音障害

これらの図より，スペクトログラムでは音声に比べ体内 伝導音では高周波成分が弱くなっていることが分かる，特に 機能障害者 5 は調音ができないため, 気道音声でも高周波成 分がかなり減衰している，また，時間波形においては健常者 のように一音節ごとにはっきりとした発声ではなく, 各音節 間がつながるような不明瞭な発声になっていることが分かる。

以上のように, 障害者は健常者と音声が異なるため認識率 の低下が生じている。

\section{3 音節区間の推定}

前述のように本システムは，体内伝導音を音声認識するこ とで音節区間を推定し, 音節区間ごとに合成音声を生成する。

本研究で提案したLPCによる音声合成の適切性を評価す るため, 人間が体内伝導音を聴取し，その音声波形を確認し ながら手作業で各音節区間を決定するヒューリスティックな 手法で区間推定して生成した合成音声の認識実験を行った。 この手法で区間推定を行うことで，各音節の区間推定がほほ 正確に推定できていると仮定することができる.

また，システムによる自動区間推定を実現するため入力音 声の連続サブワード認識（Continuous Sub-word Recognition, CSR） $[19,20]$ による区間推定で生成した合成音声の認識実験 も行った. CSR は入力音声を $25 \mathrm{~ms}$ の時間フレームで $10 \mathrm{msず}$ つシフトしながら連続認識させ, その認識結果をもとに入力 音声の単音節との対応付けを行い, 各音節区間を推定した。

\section{4 合成音声認識実験の結果}

単語認識結果を図 8 に示す。比較のため気道音声および上 唇から取得した体内伝導原音の認識結果も記載する.

ヒューリスティックな手法拉よびCSRで生成した合成音声 は全ての被験者で上唇の体内伝導音と比較して認識率が大幅

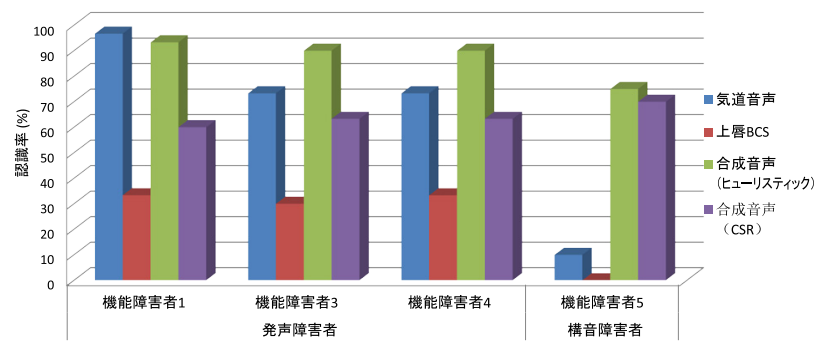

図8 合成音声の音声認識結果
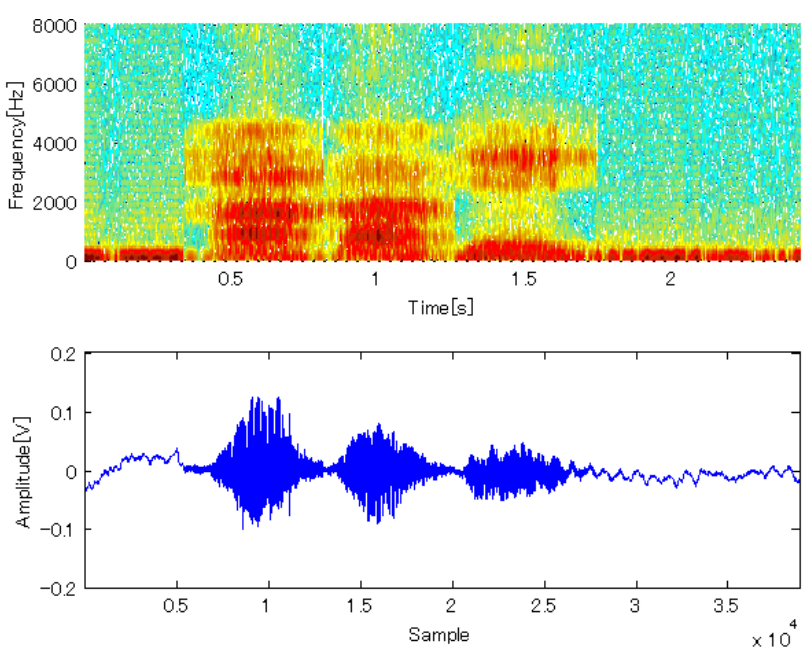

図 9 機能障害者5の合成音声（ヒューリスティック）

に向上していることが確認できる。

ヒューリスティックな手法で生成した合成音声は気道音声 に対して機能障害者1（声帯ポリープ患者）では若干低下す るが，それ以外は同水準以上の認識率である。特に構音障害 者に関しては，元々 $10 \%$ であった認識率が $75 \%$ まで上昇し た。これは本来, 高域成分がほとんど現れなかった被験者気 道音声に対し，合成音声では高域成分が回復できたためだと 考えられる。図9に機能障害者5の音声および体内伝導音か ら生成した合成音声のスペクトログラム，音声波形を示す。

四からも $2 \mathrm{KHz}$ 以上の高域部分が回復しているのがわかる.

以上の結果より，入力された体内伝導音声の音節区間の推 定さえ正しく行えれば，LPCによる合成音声は障害者気道 音声と同水準以上の音声を表現できることが確認できた。

CSRに基づく合成音声は，ヒューリスティックな手法で 区間推定した合成音声ほど認識率は向上しなかったが, 全被 験者で認識率が $60 \%$ 以上に向上されたことから，CSRによ る体内伝導音認識の自動化が可能であることが確認できた。

\section{4. 調音素性分析による音声評価実験}

\section{1 実験の目的}

調音素性とは「調音位置」「有声／無声」「調音様式」といっ た音声の基本的な分析単位である [21]。このうち「調音位 置」は音声を発声 (調音) する際, 舌の一部が口蓋のどこに 最も近づくかを「唇」「歯茎」「硬口蓋」「軟口蓋」「声門」等 であらわしたものである。「有声／無声」は声帯振動の有無 を表し，「調音様式」は「閉鎖」「摩擦」「はじき」「わたり」 といった発声器官内の空気の流れや音声の共鳴の仕方を変化 させる方法を表すものである. 日本語における母音は通常, 声帯の振動を伴った呼気が妨害を受けずに共振して起こる 音であり,「唇の丸め (開口度)」「舌の前後位置」の二つの情報 で音が決定される，また，子音は口の中で空気の流れを妨害 することによって発する音であり,「調音位置」「有声／無声」 「調音様式」の他, 拗音, 鼻音, 口蓋化といった素性がある. 
音声データベース（表 1) の機能障害者 5 は構音障害者であ り，音声生成の過程で調音することができず，発声が非常に 不明瞭になる。そこで, 本支援システムを用いて機能障害者 5 の体内伝導音から生成した合成音声と気道音声に対して聴取 実験および調音素性分析を行い，各音声に含まれる調音素性 の伝達率を調査した，合成音声の調音素性伝達率が気道音声 と比較して向上していればシステムに調音機能再現性がある と確認できる。

\section{2 実験の方法}

使用する音声デー夕はモーラから子音毎に1つずつ選定し た単音節 32 個を用いた。また入力音声は機能障害者 5 の 気道音声, 上唇の体内伝導音からヒューリスティック手法で 生成した合成音声，そして健常者 1 の気道音声の 3 種類と した。被験者は日本語を母国語とする正常な聴力を有する 22 歳 29 歳の日本人成人 9 名 (男性 5 名, 女性 4 名) である.

実験は音声刺激をヘッドフォンで両耳提示し, 被験者は聴 取した音と同じまたはもっとも近い単音節を $\mathrm{PC}$ 上に表示さ れたモーラ表（図10）から選択した。また，本実験では調音 素性ごとに検討するため，実験を母音のみ提示するものと 拗音/ $\mathrm{j} /$ を含む子音のみ提示するものの 2 種類に分けた.

\section{3 母音提示実験の結果}

表 2 に，健常者，障害者気道音声および合成音声を提示し た結果を示す。

各表の行は提示された母音を表しており，各列は回答され た母音を表している。

3 種類の音声で比較すると, 健常者気道音声と合成音声で は正答率は $100 \%$ になっている。 それに対して, 障害者気道

表2 母音提示実験結果

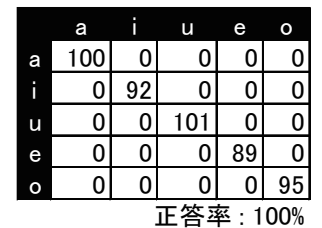

(a) 健常者気道音声

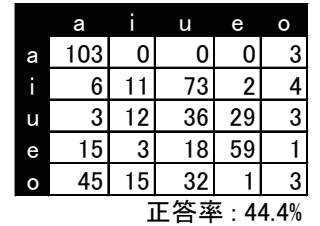

(b) 機能障害者 5 気道音声

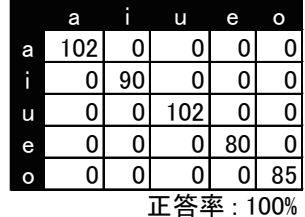

(c) 合成音声 (ヒューリスティック)

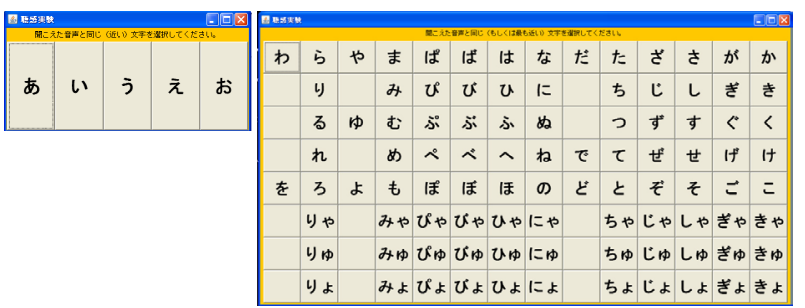

図10 聴取実験に用いた回答画面
音声では正答率はわずか $44.4 \%$ であり，提示された母音を 半数以上誤認識した結果となっている。障害者音声として使 用した音源は構音障害者の気道音声であり，調音できないと いう音声の特徵が原因となって混同（聞き間違い）が多発し たと考えられる。それに対し，合成音声では一切の混同が生 じていない，合成音声が母音を生成する調音素性を完全に再 現できているためと考えられる

機能障害者 5 の気道音声に注目すると，母音/i/と/u/の間で 多数の混同が生じていることが分かる。そこで，障害者原音 声において母音の混同が生じた原因を特定するため, 混同が起 こる音素はそれを構成する調音素性が正しく伝達されていな いと仮定して Sequential information analysis (SINFA) [22-24] を用いて調音素性分析を行った。

\subsection{SINFAによる母音の調音素性伝達率解析}

SINFAは聴取実験の結果である混同行列と，解析したい 調音素性を定義した素性行列の2つの行列を用いることで, 定義した調音素性の伝達率を解析することができる。本実験 では，混同行列として表2（b)，表2（c）を使用し，素性行列 として表3を使用した

SINFAによる解析結果を表 4 に示す

素性伝達の指標である関与率をみると，表4より障害者気 道音声では $72.2 \%$ であるが，合成音声では $100 \%$ あるる。 この結果からも本システムの合成音声は母音の素性情報が正

しく伝達されていることが確認できた。

また，障害者気道音声では「舌の前後」情報はわずか $7.4 \%$, 「開口度」情報も $31 \%$ しか伝達されていない，対して合成音 声では，両情報の伝達率は $100 \%$ となっており，本システム の利用で「舌の前後」,「開口度」の情報を完全に再現できる ことが確認できた。特に機能障害者 5 は, 事故により舌と顎 の一部を損失しており, 通常の発声では舌を使う調音は全く できない。また，開口度も制限されているため，それらの 素性情報も伝達されにくいことが予想されたが，SINFAに よる解析で予想が正しいことが確認できた.

\section{5 子音提示実験の結果}

表5 から表7に，それぞれ健常者気道音声，障害者気道音 声，合成音声による子音提示実験の結果を示す

表3 SINFAで解析する母音の素性行列

\begin{tabular}{|l|c|c|c|c|c|}
\hline \multicolumn{1}{|c|}{ 素性 } & a & $\mathbf{i}$ & $\mathbf{u}$ & $\mathbf{e}$ & $\mathbf{0}$ \\
\hline 舌の位置 & 中 & 前 & 後 & 前 & 後 \\
\hline 開口度 & 大 & 狭 & 狭 & 中 & 中 \\
\hline
\end{tabular}

表4 母音のSINFA 解析結果

\begin{tabular}{|c|c|c|c|c|}
\hline \multirow{2}{*}{ 素性 } & \multicolumn{2}{|c|}{ 機能障害者5気道音声 } & \multicolumn{2}{|c|}{ 合成音声(ヒューリスティツク) } \\
\hline & 伝達量 & 伝達率 & 伝達量 & 伝達率 \\
\hline 舌の位置 & 0.045 & $7.4 \%$ & 1.541 & $100.0 \%$ \\
\hline 開口度 & 0.477 & $31.0 \%$ & 0.774 & $100.0 \%$ \\
\hline 情報伝達量 & \multicolumn{2}{|c|}{0.522} & \multicolumn{2}{|c|}{2.315} \\
\hline 総情報伝達量 & \multicolumn{2}{|c|}{0.723} & \multicolumn{2}{|c|}{2.316} \\
\hline 関与率 & \multicolumn{2}{|c|}{$722 \%$} & \multicolumn{2}{|c|}{$100.0 \%$} \\
\hline
\end{tabular}


表5 子音提示実験結果 : 健常者気道音声

\begin{tabular}{|c|c|c|c|c|c|c|c|c|c|c|c|c|c|c|c|c|c|c|c|c|c|c|c|c|c|c|c|c|}
\hline & b & bj & ch & d & f & $\mathrm{g}$ & gj & $\mathrm{h}$ & hi & $\mathrm{ji}$ & k & kj & $\mathrm{m}$ & $\mathrm{mj}$ & $\mathrm{n}$ & nj & $\mathrm{p}$ & pj & $\mathrm{r}$ & $\mathrm{rj}$ & $\mathrm{s}$ & sh & $\mathrm{t}$ & ts & $\mathrm{w}$ & $\mathrm{y}$ & z & miss \\
\hline b. & 50 & 0 & 0 & 0 & 0 & 0 & 0 & 0 & 0 & 0 & 0 & 0 & 0 & 0 & 0 & 0 & 0 & 0 & 0 & 0 & 0 & 0 & 0 & 0 & 0 & 0 & 0 & 0 \\
\hline bj & 0 & 36 & 0 & 0 & 0 & & 0 & 0 & 0 & 0 & 0 & 0 & 0 & 0 & 0 & 0 & 0 & 0 & 0 & 0 & 0 & 0 & 0 & 0 & 0 & 0 & 0 & \\
\hline ch. & ${ }_{0}^{0}$ & 0 & 97 & ${ }_{4}^{0}$ & 0 & $\begin{array}{l}0 \\
0\end{array}$ & 0 & 0 & ${ }_{0}^{0}$ & 1 & $\begin{array}{l}0 \\
0\end{array}$ & $\begin{array}{l}0 \\
0\end{array}$ & 0 & $\begin{array}{l}0 \\
0\end{array}$ & 0 & 0 & 0 & 0 & 0 & 0 & 0 & 0 & 0 & 0 & 0 & 0 & 0 & 0 \\
\hline & 0 & 0 & 0 & 43 & 0 & $\begin{array}{l}0 \\
0\end{array}$ & 0 & 0 & 0 & ${ }_{0}^{0}$ & 0 & 0 & 0 & 0 & 0 & 0 & 0 & 0 & 0 & 0 & 0 & ${ }_{0}^{0}$ & 0 & 0 & 0 & 0 & 0 & 0 \\
\hline & $\begin{array}{l}1 \\
0\end{array}$ & 0 & ${ }_{0}^{0}$ & ${ }_{0}^{0}$ & & $\begin{array}{c}0 \\
4\end{array}$ & & $\begin{array}{l}0 \\
0\end{array}$ & $\begin{array}{l}0 \\
0\end{array}$ & & $\begin{array}{l}0 \\
0\end{array}$ & & $\begin{array}{l}0 \\
0\end{array}$ & & $\begin{array}{l}0 \\
0\end{array}$ & & & & & & & & & & & & & 0 \\
\hline $\mathrm{gj}$ & 0 & 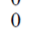 & $\begin{array}{l}0 \\
0\end{array}$ & $\begin{array}{l}0 \\
0\end{array}$ & $\begin{array}{l}0 \\
0\end{array}$ & $\begin{array}{c}41 \\
0\end{array}$ & $\begin{array}{l}0 \\
41\end{array}$ & $\begin{array}{l}0 \\
0\end{array}$ & $\begin{array}{l}0 \\
0\end{array}$ & $\begin{array}{l}0 \\
0\end{array}$ & $\begin{array}{l}0 \\
0\end{array}$ & $\begin{array}{l}0 \\
0\end{array}$ & $\begin{array}{l}0 \\
0\end{array}$ & $\begin{array}{l}0 \\
0\end{array}$ & $\begin{array}{l}0 \\
0\end{array}$ & $\begin{array}{l}0 \\
0\end{array}$ & 0 & $\begin{array}{l}0 \\
0\end{array}$ & $\begin{array}{l}0 \\
0\end{array}$ & 19 & 0 & 0 & 0 & $\begin{array}{l}0 \\
0\end{array}$ & 0 & 0 & $\begin{array}{l}0 \\
0\end{array}$ & \\
\hline $\mathrm{h}$ & 0 & 0 & 0 & 0 & 0 & 0 & 0 & 40 & 0 & 0 & 0 & 0 & 0 & 0 & 0 & 0 & 10 & 0 & 0 & 0 & 0 & 0 & 0 & 0 & 0 & 0 & 0 & 0 \\
\hline hi & 0 & 0 & 0 & 0 & 0 & 0 & 0 & 0 & 103 & 0 & 0 & 0 & 0 & 0 & 0 & 0 & 0 & 0 & 0 & 0 & 0 & 0 & 0 & 0 & 0 & 0 & 0 & 0 \\
\hline $\mathrm{ji}$ & 0 & 0 & 0 & 0 & 0 & 0 & 0 & 0 & 0 & 114 & 0 & 0 & 0 & 0 & 0 & 0 & 0 & 0 & 0 & 0 & 0 & 0 & 0 & 0 & 0 & 0 & 0 & 0 \\
\hline & 0 & 0 & 0 & 0 & & $\begin{array}{l}0 \\
0\end{array}$ & 0 & 0 & 0 & 0 & 45 & 0 & 0 & 0 & 0 & 0 & 0 & 0 & 0 & 0 & 0 & 0 & 0 & 0 & & & 0 & 0 \\
\hline & $\begin{array}{l}0 \\
0\end{array}$ & $\begin{array}{l}0 \\
0\end{array}$ & $\begin{array}{l}1 \\
0\end{array}$ & 0 & $\begin{array}{l}0 \\
0\end{array}$ & 0 & $\begin{array}{l}0 \\
0\end{array}$ & $\begin{array}{l}0 \\
0\end{array}$ & $\begin{array}{l}0 \\
0\end{array}$ & $\begin{array}{l}0 \\
0\end{array}$ & & $\begin{array}{c}48 \\
0\end{array}$ & $\begin{array}{l}0 \\
61\end{array}$ & $\begin{array}{l}0 \\
0\end{array}$ & 0 & $\begin{array}{l}0 \\
0\end{array}$ & 0 & & & & & $\begin{array}{l}0 \\
0 \\
0\end{array}$ & & & & & & \\
\hline $\mathrm{m}$ & 0 & 0 & 0 & 0 & & 0 & 0 & 0 & 0 & 0 & 0 & 0 & 0 & 49 & 0 & 7 & 0 & 0 & 0 & 0 & 0 & 0 & 0 & 0 & & & & 0 \\
\hline & 0 & 0 & 0 & & 0 & 0 & 0 & 0 & 0 & 0 & 0 & 0 & 0 & 0 & 58 & 1 & 0 & & & & & 0 & 0 & 0 & & & & 0 \\
\hline $\mathrm{nj}$ & 0 & 0 & 0 & & 0 & 0 & 0 & 0 & 0 & 0 & 0 & 0 & 0 & 0 & 0 & 99 & & & & 0 & 0 & 0 & 0 & 0 & & & 0 & \\
\hline & 1 & 0 & 0 & 0 & 0 & 0 & 0 & 0 & 0 & 0 & 0 & 0 & 0 & 0 & 0 & 0 & 44 & & & & 0 & 0 & 0 & 0 & & & 0 & 0 \\
\hline pj & 0 & 0 & 0 & 0 & 0 & 0 & 0 & 0 & 0 & 0 & & 0 & 0 & 0 & $\begin{array}{l}0 \\
0\end{array}$ & $\begin{array}{l}0 \\
0\end{array}$ & ${ }_{0}^{0}$ & 51 & & & $\begin{array}{l}0 \\
0\end{array}$ & ${ }_{0}^{0}$ & ${ }_{0}^{0}$ & 0 & & & ${ }_{0}^{0}$ & ${ }_{0}^{0}$ \\
\hline & & & & & & & & & $\begin{array}{l}0 \\
0\end{array}$ & & & & & & & & & & & & & & & & & & & \\
\hline $\begin{array}{l}\text { tu } \\
\text { s }\end{array}$ & 0 & 0 & 0 & & 0 & 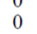 & & & 0 & 0 & & & 0 & 0 & & & & & & & & & & & & & & \\
\hline sh & 0 & 0 & 0 & & 0 & & 0 & 0 & 0 & 0 & & 0 & 0 & 0 & & 0 & 0 & & & & & 111 & & & & & & \\
\hline & 0 & 0 & 0 & 4 & 0 & 0 & 0 & & 0 & 0 & 0 & 0 & 0 & 0 & 0 & 0 & 0 & & & & 0 & 0 & 42 & 0 & & & 0 & 0 \\
\hline & 0 & 0 & 0 & 0 & 0 & 0 & 0 & 0 & 0 & 0 & 0 & 0 & 0 & 0 & 0 & 0 & 1 & & ? & & 0 & 0 & 1 & 43 & & & 0 & 0 \\
\hline & 0 & ${ }_{0}^{0}$ & ${ }_{0}^{0}$ & 0 & $\begin{array}{l}0 \\
0 \\
0\end{array}$ & & 0 & & ${ }_{0}^{0}$ & & & & & & & & & & & & & $\begin{array}{l}0 \\
0\end{array}$ & & & & & & 0 \\
\hline & $\begin{array}{l}0 \\
0\end{array}$ & $\begin{array}{l}0 \\
0\end{array}$ & $\begin{array}{l}0 \\
0\end{array}$ & & & & $\begin{array}{l}0 \\
0\end{array}$ & $\begin{array}{l}0 \\
0\end{array}$ & $\begin{array}{l}0 \\
0\end{array}$ & $\begin{array}{l}0 \\
0\end{array}$ & & & $\begin{array}{l}0 \\
0\end{array}$ & $\begin{array}{l}0 \\
0\end{array}$ & & $\begin{array}{l}0 \\
0\end{array}$ & $\begin{array}{l}0 \\
0\end{array}$ & $\begin{array}{l}0 \\
0\end{array}$ & & & & 0 & & & & & $\begin{array}{l}0 \\
46\end{array}$ & $\begin{array}{l}0 \\
0\end{array}$ \\
\hline & & & & & & & & & & & & & & & & & & & & & & & & & & & & 20 \\
\hline
\end{tabular}

表 6 子音提示実験結果 : 機能障害者 5 気道音声

\begin{tabular}{|c|c|c|c|c|c|c|c|c|c|c|c|c|c|c|c|c|c|c|c|c|c|c|c|c|c|c|c|c|}
\hline & b & $\mathrm{bj}$ & ch & d & $\mathrm{f}$ & $\mathrm{g}$ & gj & h & hi & ji & $\mathrm{k}$ & $\mathrm{kj}$ & $\mathrm{m}$ & $\mathrm{mj}$ & $\mathrm{n}$ & $\mathrm{nj}$ & $\mathrm{p}$ & $\mathrm{pj}$ & $r$ & $\mathrm{rj}$ & $\mathrm{S}$ & sh & $\mathrm{t}$ & ts & w & $\mathrm{y}$ & z & miss \\
\hline b & 1 & 0 & 0 & 1 & 0 & 4 & 0 & 0 & 0 & 0 & 0 & 0 & 8 & 2 & 22 & 2 & 0 & 0 & 4 & 0 & 0 & 0 & 0 & 0 & 1 & 1 & 0 & 0 \\
\hline bj & 1 & 1 & 0 & 0 & 0 & 0 & 0 & 0 & 0 & 0 & 0 & 0 & 13 & 2 & 24 & 3 & 0 & 2 & 1 & 0 & 0 & 0 & 0 & 0 & 1 & 2 & 0 & 0 \\
\hline ch & 8 & 5 & 0 & 1 & 8 & 2 & 1 & 5 & 0 & 0 & 1 & 0 & 6 & $\overline{1}$ & 10 & 0 & 47 & $\overline{1}$ & 5 & 0 & 1 & 0 & 14 & 0 & 1 & 0 & 0 & 0 \\
\hline $\mathrm{d}$ & 4 & 0 & 0 & 1 & 0 & 3 & 1 & 1 & 0 & 2 & 1 & 0 & 18 & 3 & 33 & 7 & 1 & 0 & 3 & 0 & 0 & 0 & 0 & 0 & 4 & 0 & 0 & 0 \\
\hline $\mathrm{f}$ & 3 & 0 & 0 & 1 & 12 & 3 & 0 & 2 & 0 & 0 & 1 & 0 & 7 & 0 & 1 & 0 & 17 & 1 & 5 & 0 & 0 & 0 & 1 & 1 & 0 & 2 & 0 & 0 \\
\hline $\mathrm{g}$ & 7 & 0 & 0 & 3 & 0 & 2 & 0 & 7 & 0 & 0 & 0 & 0 & 9 & 0 & 19 & 0 & 5 & 2 & 3 & 0 & 0 & 0 & 2 & 0 & 6 & 1 & 0 & 0 \\
\hline gj & 1 & 2 & 0 & 1 & 0 & 0 & 0 & 1 & 0 & 0 & 0 & 0 & 11 & 8 & 26 & 3 & 3 & 3 & 3 & 2 & 0 & 0 & 0 & 0 & 1 & 1 & 0 & 0 \\
\hline $\mathrm{h}$ & 1 & 0 & 0 & 0 & 0 & 1 & 0 & 12 & 0 & 0 & 0 & 0 & 1 & 0 & 0 & 0 & 30 & 0 & 1 & 0 & 1 & 0 & 2 & 0 & 1 & 0 & 0 & 0 \\
\hline hi & 1 & 0 & 0 & 0 & 31 & 1 & 0 & 47 & 3 & 0 & 1 & 0 & 3 & 0 & 4 & 0 & 9 & 0 & 0 & 0 & 0 & 0 & 6 & 0 & 1 & 3 & 0 & 0 \\
\hline ji & 4 & 9 & 0 & 0 & 3 & 4 & 0 & 0 & 1 & 0 & 3 & 0 & 22 & 2 & 42 & 4 & 2 & 1 & 4 & 1 & 0 & 0 & 0 & 0 & 2 & 6 & 0 & 0 \\
\hline $\mathrm{k}$ & 1 & 0 & 0 & 0 & 0 & 0 & 0 & 14 & 0 & 0 & 3 & 0 & 0 & 0 & 1 & 0 & 32 & 0 & 2 & 0 & 1 & 0 & 1 & 0 & 1 & 0 & 0 & 0 \\
\hline $\mathrm{kj}$ & 1 & 0 & 0 & 0 & 0 & 1 & 0 & 6 & 0 & 0 & 3 & 0 & 1 & 0 & 0 & 0 & 43 & 0 & 1 & 0 & 0 & 0 & 2 & 0 & 0 & 0 & 0 & 0 \\
\hline $\mathrm{m}$ & 2 & 1 & 0 & 0 & 0 & 2 & 1 & 1 & 0 & 0 & 0 & 0 & 10 & 3 & 16 & 7 & 0 & 0 & 6 & 0 & 0 & 0 & 0 & 0 & 2 & 1 & 0 & 0 \\
\hline $\mathrm{mj}$ & 0 & 0 & 0 & 1 & 0 & 2 & 0 & 0 & 3 & 0 & 0 & 0 & 5 & 11 & 19 & 8 & 0 & 0 & 8 & 3 & 0 & 0 & 0 & 0 & 1 & 7 & 0 & 0 \\
\hline $\mathrm{n}$ & 1 & 2 & 0 & 2 & 0 & 1 & 0 & 0 & 0 & 0 & 0 & 0 & 17 & 1 & 21 & 1 & 0 & 1 & 7 & 0 & 0 & 0 & 0 & 0 & 6 & 0 & 0 & 0 \\
\hline nj & 6 & 2 & 0 & 1 & 0 & 7 & 0 & 0 & 0 & 0 & 2 & 0 & 24 & 10 & 44 & 2 & 3 & 0 & 9 & 0 & 0 & 0 & 0 & 0 & 1 & 2 & 1 & 1 \\
\hline $\mathrm{p}$ & 2 & 0 & 0 & 0 & 1 & 0 & 0 & 30 & 0 & 0 & 4 & 0 & 5 & 0 & 1 & 0 & 6 & 1 & 1 & 0 & 0 & 0 & 0 & 0 & 5 & 0 & 0 & 0 \\
\hline pj & 2 & 0 & 0 & 2 & 0 & 0 & 0 & 8 & 0 & 0 & 1 & 0 & 0 & 0 & 1 & 0 & 19 & 2 & 0 & 0 & 1 & 0 & 12 & 0 & 0 & 0 & 1 & 0 \\
\hline r & 4 & 6 & 0 & 1 & 0 & 3 & 0 & 1 & 0 & 0 & 0 & 0 & 2 & 1 & 16 & 1 & 0 & 1 & 11 & 1 & 0 & 0 & 1 & 0 & 1 & 10 & 0 & 0 \\
\hline $\mathrm{rj}$ & 0 & 4 & 0 & 3 & 0 & 0 & 0 & 0 & 0 & 0 & 0 & 0 & 2 & 4 & 22 & 2 & 1 & 1 & 6 & 0 & 0 & 0 & 0 & 0 & 0 & 1 & 0 & 0 \\
\hline $\mathrm{s}$ & 2 & 0 & 0 & 0 & 0 & 0 & 0 & 5 & 0 & 0 & 0 & 0 & 1 & 0 & 0 & 0 & 37 & 0 & 0 & 0 & 0 & 0 & 13 & 0 & 2 & 0 & 0 & 0 \\
\hline sh & 4 & 0 & 0 & 2 & 10 & 0 & 0 & 4 & 1 & 0 & 5 & 0 & 6 & 0 & 4 & 2 & 38 & 7 & 3 & 0 & 0 & 0 & 14 & 1 & 0 & 5 & 0 & 0 \\
\hline $\mathrm{t}$ & 4 & 0 & 0 & 0 & 0 & 1 & 0 & 31 & 0 & 0 & 6 & 0 & 0 & 0 & 2 & 0 & 9 & 0 & 1 & 0 & 2 & 0 & 4 & 0 & 2 & 0 & 0 & 0 \\
\hline ts & 0 & 0 & 0 & 0 & 20 & 0 & 0 & 1 & 0 & 0 & 0 & 0 & 7 & 0 & 16 & 2 & 4 & 0 & 0 & 0 & 0 & 0 & 0 & 0 & 0 & 2 & 0 & 0 \\
\hline w & 9 & 5 & 0 & 0 & 0 & 1 & 1 & 2 & 0 & 0 & 0 & 0 & 3 & 4 & 9 & 1 & 2 & 3 & 2 & 2 & 0 & 0 & 1 & 0 & 4 & 5 & 0 & 1 \\
\hline $\mathrm{y}$ & 0 & 6 & 0 & 0 & 0 & 1 & 0 & 0 & 0 & 0 & 0 & 0 & 12 & 6 & 19 & 2 & $\overline{0}$ & 0 & 2 & $\overline{1}$ & 0 & 0 & 0 & 0 & 2 & 0 & 0 & 0 \\
\hline$z$ & 1 & 1 & 0 & 0 & 0 & 1 & 0 & 1 & 0 & 0 & 0 & 0 & 3 & 6 & 25 & 2 & 1 & 1 & 4 & 1 & 0 & 0 & 0 & 0 & 1 & 1 & 0 & 0 \\
\hline \multicolumn{29}{|c|}{ 正答率： $5.9 \%$} \\
\hline
\end{tabular}

表7 子音提示実験結果 : 合成音声（ヒューリスティック）

\begin{tabular}{|c|c|c|c|c|c|c|c|c|c|c|c|c|c|c|c|c|c|c|c|c|c|c|c|c|c|c|c|c|}
\hline & b & bj & ch & d & f & $\mathrm{g}$ & gj & h & hi & ji & $\mathrm{k}$ & $\mathrm{kj}$ & $\mathrm{m}$ & $\mathrm{mj}$ & $\mathrm{n}$ & $\mathrm{nj}$ & $\mathrm{p}$ & $\mathrm{pj}$ & $\mathrm{r}$ & $\mathrm{rj}$ & $\mathrm{s}$ & sh & $t$ & ts & w & $\mathrm{y}$ & z & miss \\
\hline b & 8 & 0 & 0 & 1 & 0 & 5 & 0 & 6 & 0 & 0 & 4 & 0 & 5 & 0 & 13 & 0 & 1 & 0 & 2 & 0 & 0 & 0 & 1 & 0 & 14 & 1 & 0 & 0 \\
\hline bj & 5 & 7 & 0 & 0 & 0 & 0 & 0 & 1 & 0 & 0 & 0 & 0 & 4 & 6 & 10 & 5 & 2 & 0 & 3 & 2 & 0 & 0 & 0 & 0 & 4 & 5 & 0 & 1 \\
\hline ch & 7 & 0 & 1 & 3 & 0 & 18 & 0 & 0 & 3 & 5 & 7 & 0 & 0 & 0 & 1 & 6 & 27 & 0 & 15 & 0 & 1 & 0 & 14 & 0 & 1 & 0 & 1 & 0 \\
\hline $\mathrm{d}$ & 5 & 0 & 0 & 2 & 0 & 1 & 0 & 6 & 1 & 0 & 1 & 0 & 3 & 0 & 5 & 2 & 1 & 0 & 16 & 1 & 0 & 0 & 0 & 0 & 4 & 7 & 1 & 0 \\
\hline f & 16 & 0 & 0 & 0 & 4 & 3 & 0 & 0 & 0 & 0 & 5 & 0 & 6 & 0 & 6 & 0 & 6 & 0 & 2 & 0 & 0 & 0 & 0 & 0 & 0 & 1 & 0 & 0 \\
\hline $\mathrm{g}$ & 14 & 0 & 0 & 1 & 0 & 0 & 0 & 7 & 0 & 0 & 4 & 0 & 3 & 0 & 2 & 0 & 4 & 0 & 1 & 0 & 0 & 0 & 6 & 0 & 10 & 1 & 1 & 0 \\
\hline gj & 16 & 3 & 0 & 1 & 1 & 3 & 0 & 0 & 0 & 0 & 0 & 0 & 6 & 2 & 4 & 0 & 9 & 1 & 13 & 3 & 0 & 0 & 1 & 0 & 2 & 3 & 0 & 0 \\
\hline $\mathrm{h}$ & 0 & 0 & 0 & 1 & 0 & 0 & 0 & 13 & 0 & 0 & 4 & 0 & 1 & 0 & 0 & 0 & 20 & 0 & 0 & 0 & 0 & 0 & 5 & 0 & 5 & 1 & 0 & 0 \\
\hline hi & 5 & 0 & 1 & 0 & 0 & 5 & 0 & 27 & 7 & 0 & 25 & 0 & 3 & 0 & 0 & 4 & 12 & 0 & 11 & 0 & 1 & 3 & 0 & 0 & 3 & 1 & 0 & 0 \\
\hline ji & 16 & 7 & 4 & 1 & 0 & 6 & 0 & 2 & 5 & 4 & 9 & 0 & 6 & 0 & 9 & 10 & 7 & 0 & 17 & 6 & 0 & 4 & 2 & 0 & 1 & 4 & 2 & 1 \\
\hline $\mathrm{k}$ & 1 & 0 & 0 & 0 & 0 & 0 & 0 & 2 & 0 & 0 & 3 & 0 & 1 & 0 & 0 & 0 & 43 & 0 & 0 & 0 & 3 & 0 & 7 & 0 & 2 & 0 & 0 & 0 \\
\hline $\mathrm{kj}$ & 2 & 0 & 0 & 0 & 0 & 2 & 0 & 3 & 0 & 0 & 26 & 0 & 1 & 0 & 1 & 0 & 16 & 0 & 1 & 0 & 2 & 0 & 2 & 0 & 8 & 0 & 0 & 0 \\
\hline $\mathrm{m}$ & 8 & 3 & 0 & 2 & 0 & 1 & 0 & 6 & 0 & 0 & 3 & 0 & 9 & 2 & 9 & 1 & 3 & 1 & 4 & 0 & 2 & 0 & 6 & 0 & 9 & 3 & 1 & 0 \\
\hline $\mathrm{mj}$ & 5 & 2 & 0 & 3 & 0 & 0 & 2 & 4 & 0 & 0 & 2 & 0 & 9 & 2 & 8 & 2 & 1 & 0 & 10 & 8 & 0 & 0 & 1 & 0 & 1 & 8 & 0 & 0 \\
\hline $\mathrm{n}$ & 4 & 2 & 0 & 1 & 0 & 2 & 0 & 2 & 0 & 0 & 0 & 0 & 4 & 5 & 12 & 1 & 1 & 0 & 6 & 2 & 0 & 0 & 1 & 0 & 7 & 2 & 0 & 0 \\
\hline nj & 13 & 3 & 1 & 1 & 0 & 17 & 0 & 2 & 3 & 1 & 2 & 0 & 16 & 2 & 17 & 12 & 2 & 1 & 10 & 0 & 0 & 0 & 1 & 0 & 1 & 4 & 2 & 0 \\
\hline $\mathrm{p}$ & 1 & 0 & 0 & 0 & 0 & 0 & 0 & 18 & 0 & 0 & 8 & 0 & 0 & 0 & 2 & 0 & 14 & 0 & 0 & 0 & 1 & 0 & 9 & 0 & 5 & 1 & 1 & 0 \\
\hline $\mathrm{pj}$ & 0 & 1 & 0 & 1 & 0 & 0 & 0 & 0 & 0 & 0 & 2 & 1 & 1 & 0 & 0 & 0 & 35 & 1 & 1 & 0 & 1 & 0 & 19 & 0 & 1 & 1 & 0 & 0 \\
\hline $\mathrm{r}$ & 11 & 1 & 0 & 2 & 0 & 5 & 0 & 0 & 0 & 0 & 0 & 0 & 2 & 1 & 3 & 2 & 2 & 1 & 6 & 1 & 0 & 0 & 4 & 0 & 2 & 4 & 0 & 0 \\
\hline $\mathrm{rj}$ & 12 & 2 & 0 & 1 & 0 & 1 & 1 & 3 & 0 & 0 & 2 & 0 & 7 & 0 & 5 & 0 & 1 & 1 & 12 & 1 & 0 & 0 & 2 & 0 & 0 & 2 & 1 & 1 \\
\hline $\mathrm{s}$ & 1 & 0 & 0 & 0 & 0 & 0 & 0 & 6 & 0 & 0 & 25 & 0 & 1 & 0 & 0 & 0 & 16 & 0 & 0 & 0 & 0 & 0 & 2 & 0 & 5 & 1 & 0 & 0 \\
\hline sh & 1 & 0 & 4 & 0 & 0 & 16 & 0 & 6 & 7 & 6 & 25 & 0 & 1 & 0 & 0 & 4 & 19 & 0 & 9 & 0 & 0 & 3 & 8 & 0 & 2 & 1 & 0 & 0 \\
\hline $\mathrm{t}$ & 1 & 0 & 0 & 0 & 0 & 0 & 0 & 6 & 0 & 0 & 12 & 0 & 1 & 1 & 1 & 0 & 7 & 0 & 2 & 0 & 5 & 0 & 2 & 0 & 10 & 0 & 0 & 0 \\
\hline ts & 12 & 0 & 0 & 0 & 2 & 1 & 0 & 0 & 0 & 0 & 8 & 0 & 7 & 0 & 5 & 2 & 3 & 0 & 7 & 0 & 0 & 0 & 0 & 8 & 0 & 0 & 2 & 0 \\
\hline w & 7 & 1 & 1 & 0 & 0 & 3 & 0 & 4 & 0 & 0 & 4 & 0 & 2 & 0 & 4 & 0 & 4 & 0 & 3 & 0 & 1 & 0 & 2 & 0 & 9 & 1 & 0 & 1 \\
\hline $\mathrm{y}$ & 17 & 5 & 0 & 1 & 0 & 1 & 0 & 2 & 0 & 0 & 0 & 0 & 5 & 2 & 11 & 3 & 3 & 1 & 5 & 2 & 0 & 0 & 0 & 0 & 0 & 5 & 0 & 0 \\
\hline z & 12 & 1 & 0 & 0 & 0 & 2 & 0 & 0 & 0 & 0 & 0 & 0 & 2 & 0 & 2 & 0 & 2 & 0 & 8 & 0 & 0 & 0 & 0 & 1 & 4 & 0 & 0 & 0 \\
\hline
\end{tabular}


各表の行は提示された子音を表しており，各列は回答され た子音を表している。表中最終列 "miss" は被験者のミスに より選択肢以外を回答した回数を示している.

これらの表より健常者においては正答率 $93.2 \%$ と混同は 生じていないが，障害者気道音声では $5.9 \%$, 合成音声では $7.4 \%$ と多数の混同が生じていることがわかる.

\subsection{SINFAによる子音の調音素性伝達率解析}

母音と同様に表6および表7 の混同行列をSINFAで解析 を行った。解析に使用した素性行列 $[25,26]$ を表 8 に示す. 表9にSINFAによる解析結果を示す。比較のために健常者 の結果も載せている.

表9より, 調音素性の伝達率はおおむね障害者気道音声の 方が合成音声よりも高く, 関与率においても障害者気道音声 の方が高い. また, 解析結果の中で一部結果が出力されてい ない項目があるが, これは解析の途中で, 混同パターンに全 く関係ないと判断され削除されたためである. 以上より子音 については, 本システムで生成した合成音声では原気道音声 と比較してその認識率を高めることはできなかった. しかし, 聴取実験の正答率では合成音声の方が高いという結果であった。

SINFAによる調音素性解析は, 定義した素性のみを解析 するもので, 当然ながら素性行列で定義していない素性の伝 達率は確認できない, 障害者原音声では, 情報の総伝達量 1.002 に対して, 定義した素性の情報伝達量は 0.568 であり, $56.7 \%$ の情報しか特定できていない. 同様に合成音声では,

表8 SINFAで解析する子音の素性行列

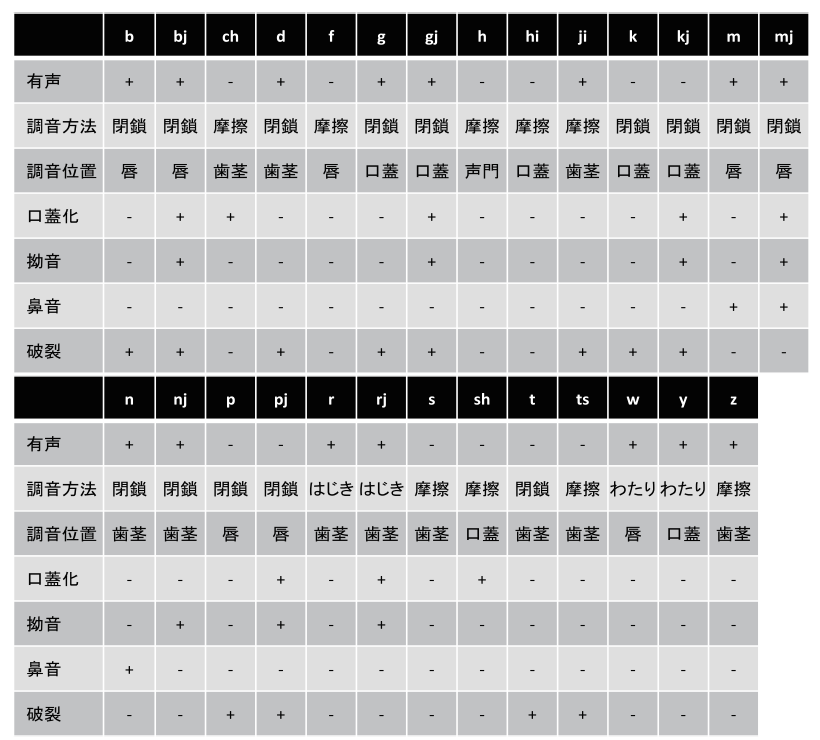

表9 子音のSINFA解析結果

\begin{tabular}{|c|c|c|c|c|c|c|}
\hline \multirow[b]{2}{*}{ 素性 } & \multicolumn{2}{|c|}{ 健常者気道音声 } & \multicolumn{2}{|c|}{ 機能障害者5氨道音声 } & \multicolumn{2}{|c|}{ 合成音声(ヒューリスティツク) } \\
\hline & 伝違量 & 伝连率 & 隹橽量 & 伝连率 & 伝连量 & 伝连率 \\
\hline 口蓋化 & 0.670 & $95.7 \%$ & 0.012 & $1.4 \%$ & - & - \\
\hline 鼻音 & 0.446 & $100.0 \%$ & - & - & - & - \\
\hline 破裂 & 0.142 & $100.0 \%$ & 0.068 & $9.9 \%$ & 0.016 & $1.6 \%$ \\
\hline 有声 & 0.641 & $92.4 \%$ & 0.434 & $43.6 \%$ & 0.191 & $19.2 \%$ \\
\hline 調音位置 & 1.163 & $90.4 \%$ & 0.044 & $3.1 \%$ & 0.092 & $7.4 \%$ \\
\hline 調音方法 & 0.476 & $89.0 \%$ & 0.011 & $3.1 \%$ & 0.037 & $3.0 \%$ \\
\hline 胁音 & 0.799 & $98.3 \%$ & - & - & 0.022 & $5.3 \%$ \\
\hline 情報伝達量 & \multicolumn{2}{|c|}{4.336} & \multicolumn{2}{|c|}{0.568} & \multicolumn{2}{|c|}{0.358} \\
\hline 総情報伝達量 & \multicolumn{2}{|c|}{4.420} & \multirow{2}{*}{\multicolumn{2}{|c|}{$\begin{array}{l}1.002 \\
5\end{array}$}} & \multicolumn{2}{|c|}{0.882} \\
\hline 関与率 & \multicolumn{2}{|c|}{$98.1 \%$} & & $56.7 \%$ & \multicolumn{2}{|c|}{$40.6 \%$} \\
\hline
\end{tabular}

情報の総伝達量 0.882 に対して定義した素性の情報伝達量は 0.358 であり，わずか $40.6 \%$ である。これらから今回定義し た素性行列では障害者原音声と合成音声の混同を捉えること ができなかったことが確認できる。引き続き解析に使う素性 行列について検討する必要がある.

\section{5. 結 言}

本研究では, 発声機能障害者を支援するための発声機能障 害者支援システムで使用する音質明瞭化手法の開発と評価を 行った.

まず，音質明瞭化手法として線形予測分析 (LPC) を用い た音声合成手法の有効性を検討した。本システムで生成した 合成音声は本来欠落している高域部分を回復することができ た，また，区間推定が正しくできた場合は，障害者体内伝導 音から生成した合成音声の認識率が健常者気道音声とほぼ同 等になることが確認できた，連続サブワード認識による自動 区間推定で作成した合成音声も認識率が $60 \%$ 以上まで改善 され，区間推定自動化の可能性も確認できた。

次に, 線形予測分析を用いて作成した合成音声を評価する ために聴取実験および調音素性分析の二つの主観評価を行っ た。音については障害者原音声で多数生じていた混同が, 合成音声で無くなっていた。 また, 子音については合成音声 が障害者原音声よりも調音素性の伝達率は低いものの, 聴取 実験の正答数は多いという結果になった。

このことから，本システムで作成した合成音声は本来， 原音声に含まれていない調音情報を再現でき, 明瞭性の向上 した合成音になっていることを確認できた。引き続き，子音 の明瞭度改善を検討し, これらの明瞭化手法を発声機能障害 者支援システムへ導入していく予定である.

なお, 本研究はJSPS 科研費 25282178 の助成を受けたも のである.

\section{参 考 文 献}

１1］国立がんセンターがん対策情報センター：がん情報サービ ス「集計表のダウンロード」(http : //ganjoho.jp/professional/ statistics/statistics.html), (参照日 2015年4月 19日).

[2] 伊福部達：音の福祉工学, コロナ社, pp.165-190, 1997.

[3] Kain, A. B., Hosom, J. P., Xiaochuan, N., van Santen, J. P. H., Fried-Oken, M. and Staehely, J.: Improving the intelligibility of dysarthric speech, Speech Communicaton, Vol.49, pp.743-759, 2007.

[4] Nakamura, K., Toda, T., Saruwatari, H. and Shikano, K.: Speaking aid system for total laryngectomees using voice conversion of body transmitted artificial speech, Proceedings of the Interspeech, pp.1395-1398, 2006.

[5] 石光俊介, 北風裕教, 土伏悌之, 柳川博文, 福島学: 体内 伝導音認識システム構築のための基礎的検討, 社団法人電 子情報通信学会 信学技報, EA2002-34, pp.25-28, 2002. 
［6］中山仁史, 石光俊介, 小田康平：体内伝導音認識を用いた 発声機能障害者支援システムの基礎検討, 日本音響学会 2007 年秋季研究発表会講演論文集, CDROM, pp.715716, 2007.

[7] Ishimitsu, S., Kitakaze, H., Tsuchibushi, Y., Yanagawa, H. and Fukushima, M.: A noise-robust speech recognition system making use of body-conducted signals, Acoust. Sci. \& Tech.25, 2, pp.166-169, 2004.

[8] 小田康平, 石光俊介, 中山仁史 : 発声機能障害者支援シス テムの構築, 第 10 回 IEEE広島支部学生シンポジウム, CDROM, pp.74-77, 2008.

[9] Nagoshi, H., Ishimitsu, S., Oda, K., Makiyama, K. and Horihata, S.: Development for speech support system using body-conducted speech, Forum Acusticum 2011, CDROM, pp.95-99, 2011.

[10] Itakura, F. and Saito, S.: An analysis-synthesis telephony based on the maximum likelihood method, Proceeding of the 6th International Commission for Acoustics, Vol.3, C-5-5, 1968.

[11] Atal, B. S. and Schroeder, M. R.: Predictive cording of Speech Signals, Proceeding of the 6th International Commission for Acoustics, Vol.3, C-5-4, 1968.

[12] Nagoshi, H., Ishimitsu, S., Oda, K., Makiyama, K. and Horihata, S.: Improving the Clarity of Body-Conducted Speech Using Linear Predictive Coefficients, ICIC EXPRESS LETTERS, PartB: Applications, Vol.2, No.3, pp.609-614, 2011.

[13] 小田康平, 石光俊介, 中山仁史, 牧山清, 堀畑聡 : 発声機 能障害者のための音声認識システムの評価, 日本機械学会 中国四国支部 第 48 期総会 - 講演会講演論文集, pp.359360,2010

[14] Itahashi, S.: A noise database and Japanese common speech data corpus, J. Acoust. Soc. Jpn, Vol.47, No.12, pp.951-953, 1991.

[15］阿部匡伸, 匂坂芳典, 梅田哲夫, 桑原尚夫：研究用日本語 音声データベース利用解説書 (連続音声デー夕編), TR-I0166, ATR 自動翻訳電話研究所, 1990.

[16]李晃伸：汎用大語彙連続音声認識エンジン Julius / Julian rev.3.3 (http : //julius.sourceforge.jp/book/Julius-book-3.3ja.pdf），2002，（参照日 2015年4月 19日）.

[17] 鹿野清宏, 河原達也, 山本幹雄, 伊藤克亘, 武田一哉, 情報処理学会: IT Text 音声認識システム, オーム社, pp.1-16, 2001.

[18] Saito, Y., Yanagwa, H., Ishimitsu, S., Kamura, K and Fukushima, M.: Improvement of the speech sound quality of the vibration pick up microphone for speech recognition under noisy environment, Proceeding of the Autumn Meeting of Acoust. Soc. Jpn., Vol.1, pp.691-692, 2001.

[19] 向當一洋, 谷口秀次, 小泉卓也 : サブワード単位離散単語 認識システムの話者依存性の改善, 電子情報通信学会技術
研究報告. SP, 音声 98(178), pp.15-21， 1998.

[20] Koizumi, T., Fukuyama, A., Mori, M. and Taniguchi, S.: Speech Recognition Based on Subword Units: Proceedings of the 3rd Joint Meeting of Acoust. Soc. Am and Acoust. Soc. Jpn, pp.1129-1134, 1996.

[21］板橋秀一, 赤羽誠, 石川泰, 大河内正明, 粕谷英樹, 桑原 尚夫, 田中和世, 新田恒雄, 矢頭隆, 渡辺隆夫 : 音声工学, 森北出版, pp.6-10, 2005.

[22］籠宮隆之，中川誠司：骨導超音波補聴器装用時の分節音異 聴パターンに対する調音素性を用いた分析，日本音響学会 秋季研究発表会講演論文集, pp.559-560, 2011.

[23] Wang, M, D.: SINFA: Multivariate uncertainty analysis for confusion matrices, Behavior Research Methods \& Instrumentation, Vol.8, Issue 5, pp.471-472, 1976.

[24] SINFA analyzing software "FIX-Feature Information Xfer", UCL Division of Psychology \& Language Sciences (http://www.phon.ucl.ac.uk/resource/software.html), (参照日2015年4月 19 日).

[25］猪塚元，猪塚恵美子：日本語の音声入門一解説と演習 （日本語教師トレーニングマニュアル），バベルプレス， pp.132-133, 2008.

[26］ジャック・ライアルズ：音声知覚の基礎, 海文堂, p.4, 2009.

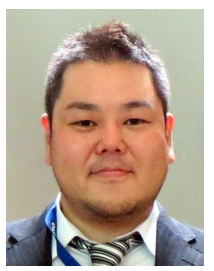

\section{福井 和敏 (非会員)}

2009年 信州大学大学院工学研究科修士課程 修了. 修士. 現在, 広島市立大学大学院シス テム工学研究科博士後期課程に在学中. 主に 発声障害者支援システムの開発に従事.

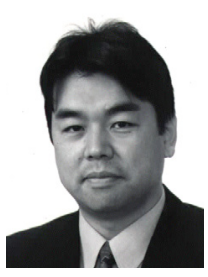

\section{石光 俊介 (正会員)}

1995 年 豊橋技術科学大学大学院博士課程修 了. 博士 (工学). 現在, 広島市立大学大学 院情報科学専攻システム科学科教授. 主に フィードフォワード・フィードバック制御の ための適応アルゴリズムの研究, サウンドデ ザイン, 時間一周波数解析掞よびノイズロバストな会話認識シ ステムの研究に従事.

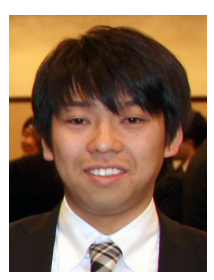

\section{名越 隼人 (非会員)}

2011 年広島市立大学大学院情報科学研究科 博士前期課程修了. 修士. 現在, 富士通株式 会社 研究開発部門でモバイル端末の開発に 従事.

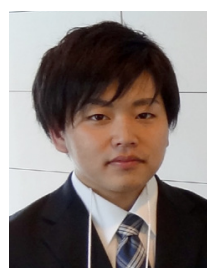

山中 貴弘 (非会員)

2013 年 広島市立大学大学院情報科学研究科 博士前期課程修了。修士. 現在, 東芝メディ カルシステムズ株式会社で医療システムの研 究に従事. 